\title{
Effects of Garlic and Juniper Berry Essential Oils on Ruminal Fermentation and on the Site and Extent of Digestion in Lactating Cows ${ }^{1}$
}

\author{
W. Z. Yang, ${ }^{2}$ C. Benchaar,† B. N. Ametaj,‡ A. V. Chaves, ${ }^{*}$ M. L. He, ${ }^{*}$ and T. A. McAllister* \\ ${ }^{*}$ Research Centre, Agriculture and Agri-Food Canada, Lethbridge, Alberta, Canada T1J 4B1 \\ †Dairy and Swine Research and Development Centre, Agriculture and Agri-Food Canada, Sherbrooke, Quebec, Canada J1M 1 Z3 \\ ‡Department of Agricultural, Food and Nutritional Science, University of Alberta, Edmonton, Canada T6G 2P5
}

\begin{abstract}
The objective of this study was to evaluate the effects of feeding essential oils from garlic (GAR) and juniper berry (JUN), or monensin (MO) on feed intake, ruminal fermentation, the site and extent of digestion, microbial protein synthesis, milk production, and immune status in dairy cows. Four midlactating Holstein cows fitted with ruminal and duodenal cannulas were used in a 4 $\times 4$ Latin square design with 21 -d periods and 4 treatments: control (no additive), MO (330 mg/cow per d), GAR (5 g/cow per d), and JUN (2 g/cow per d). Cows were fed ad libitum a TMR consisting of $40 \%$ forage and $60 \%$ barley-based concentrate. Dry matter intake averaged $20.4 \mathrm{~kg} / \mathrm{d}$ and was not affected by dietary additives. Total tract digestibilities of dry matter, organic matter, fiber, and starch were not affected by experimental treatments. However, ruminal digestibilities of dry matter and organic matter were higher $(+13 \%)$ for GAR and JUN than for the control diet, mainly because of increased crude protein digestion in the rumen. Feeding GAR and JUN increased ruminal digestion of dietary protein by $11 \%$ as compared with the control. In contrast, ruminal digestion of dietary protein was reduced by $11 \%$ with MO as compared with the control. Milk fat content was lower for MO (2.68\%) than for the GAR $(3.46 \%)$, JUN $(3.40 \%)$, and control (3.14\%) diets. No effects of GAR, JUN, or MO were observed on milk production, ruminal microbial protein synthesis, ruminal $\mathrm{pH}$, and ruminal concentrations of volatile fatty acids and ammonia N. The total and differential numbers of white blood cells as well as serum amyloid A and haptoglobin were not affected by the treatments, suggesting that additives had no effect on the immune status of cows. Results of this study indicate that supplementing dairy cows with GAR (5 g/d) and JUN (2 g/d) essential oils improved feed digestibility in the rumen, but possibly at the expense
\end{abstract}

Received May 15, 2007.

Accepted August 27, 2007.

${ }^{1}$ Contribution number 38707024 .

${ }^{2}$ Corresponding author: yangw@agr.gc.ca of a reduction in the flow of bypass protein to the small intestine. Feeding monensin could be beneficial in terms of increasing bypass protein from the rumen but did not improve feed digestion or milk production under the current experimental conditions.

Key words: garlic oil, juniper berry oil, monensin, dairy cow

\section{INTRODUCTION}

The use of antibiotic growth promoters has proven to be a useful means to improve feed efficiency and to prevent rumen acidosis in cattle (Page, 2006). However, public concerns regarding the use of antibiotics in livestock production have increased because of the development of multidrug-resistant bacteria. This has prompted interest in seeking more natural approaches to feed antibiotics, such as plant-derived essential oils (EO), as a means of improving feed efficiency and the health of dairy cattle. Essential oils are complex mixtures of secondary metabolites and volatile compounds extracted from plants through distillation methods. Essential oils have antimicrobial activities against both gram-negative and gram-positive bacteria, a property that has been attributed to the presence of terpenoid and phenolic compounds (Conner, 1993).

Recently, a number of in vitro studies have demonstrated that EO or their components have the potential to favorably alter rumen metabolism (McIntosh et al., 2003; Busquet et al., 2006). For example, McIntosh et al. (2003) showed that a commercial blend of EO inhibited the rate of deamination of $\mathrm{AA}$ and the number of hyper-ammonia-producing bacteria in 48-h in vitro batch cultures. Busquet et al. (2005c) reported that garlic oil (GAR) altered fermentation by reducing the proportion of acetate and increasing that of propionate in a manner similar to monensin (MO) in a continuous culture. Chiquette and Benchaar (2005) showed inhibitory effects of GAR and juniper berry (JUN) EO on the production of methane in vitro. Only a few studies to date have investigated the effects of $\mathrm{EO}$ or their components on digestion, ruminal fermentation, milk composition, or 
milk production in dairy cows (Benchaar et al., 2006b, 2007).

Plant extracts have been shown to stimulate the immune system, thereby enhancing the resistance of animals to inflammatory and infectious diseases. For example, Concha et al. (1996) showed that the extract of ginseng root stimulated in vitro activities of neutrophils and lymphocytes from bovine peripheral blood and milk. To our knowledge, there is no information on the immunomodulatory effects of $\mathrm{EO}$ when these compounds are included in dairy cow rations.

Monensin, a polyether antibiotic, is widely used in ruminant diets, and its beneficial effects on $\mathrm{N}$ and energy utilization are well known (McGuffey et al., 2001; Tedeschi et al., 2003). The objective of this study was to compare the effects of 3 antimicrobial agents, namely, MO, GAR, and JUN, on feed intake, ruminal fermentation, microbial protein synthesis, the site and extent of digestion, milk production, milk composition, and the immune status of lactating dairy cows.

\section{MATERIALS AND METHODS}

\section{Cows and Diets}

Four ruminally and duodenally cannulated lactating Holstein cows, averaging $705 \pm 50 \mathrm{~kg}$ of BW and $113 \pm$ $13 \mathrm{DIM}$ at the start of the experiment, were used in a $4 \times 4$ Latin square design balanced for carryover effects. The ruminal cannulas were $10 \mathrm{~cm}$ in diameter and made of soft plastic (Bar Diamond, Parma, ID). Duodenal cannulas were T-shaped and were placed proximal to the common bile and pancreatic duct, approximately $10 \mathrm{~cm}$ distal to the pylorus. Cows were fed a TMR (Table 1) without supplementation (control), or a TMR supplemented with MO (330 mg/cow per d), GAR ( $5 \mathrm{~g} / \mathrm{cow}$ per d; Allium sativum, standardized at $1.5 \%$ of allicin), or JUN ( 2 g/cow per d; Juniperus communis, standardized at $35 \%$ of $\alpha$-pinene). The EO were obtained from Axiss France SAS (Bellegarde-sur-Valserine, France) and mixed into the barley-based concentrate. Each experimental period lasted $21 \mathrm{~d}$, with $11 \mathrm{~d}$ of adaptation to experimental treatments and $10 \mathrm{~d}$ of sampling and data collection.

Cows were housed in individual tie stalls and fed a TMR ad libitum 3 times daily at 0600, 1500, and 1800 $\mathrm{h}$, and milked twice daily at 0700 and $1700 \mathrm{~h}$. All diets were formulated based on the NRC recommendations (2001) to supply sufficient energy and protein for a 700$\mathrm{kg}$ cow to produce $30 \mathrm{~kg} / \mathrm{d}$ of milk containing $3.5 \%$ fat and $3.2 \%$ protein. Cows were weighed at the beginning and at the end of each period $(0900 \mathrm{~h})$. All cows were cared for in accordance with the guidelines established by the Canadian Council on Animal Care (Ottawa, Ontario, Canada) and all animal-related procedures were
Table 1. Ingredients and chemical composition of the total mixed diet (DM basis)

\begin{tabular}{lc}
\hline Item & Amount, \% \\
\hline Ingredient $^{1}$ & \\
Barley silage $^{2}$ & 30.2 \\
Alfalfa hay $^{2}$ & 9.8 \\
Barley grain, steam-rolled $^{3}$ & 47.5 \\
Corn gluten meal $^{\text {Canola meal (Alberta Gold) }}{ }^{4}$ & 3.36 \\
Soybean meal $_{\text {Beet molasses }}$ & 2.91 \\
Canola oil & 2.91 \\
Vitamin-mineral mix $^{5}$ & 0.49 \\
Calcium carbonate & 0.90 \\
Dicalcium phosphate & 0.72 \\
Monosodium phosphate & 0.67 \\
Binding agent (Aka) & 0.36 \\
Flavoring agent & 0.04 \\
Chemical & 0.15 \\
DM, \% & 0.01 \\
OM, \% of DM & \\
CP, \% of DM & 57.5 \\
NDF, \% of DM & 93.0 \\
ADF, \% of DM & 15.8 \\
Starch, \% of DM & 32.2 \\
NE, Mcal/kg & 20.2 \\
\hline
\end{tabular}

${ }^{1}$ All ingredients were pelleted, excluding steam-rolled barley and forages.

${ }^{2}$ Composition of barley silage and alfalfa hay mix was, respectively, 33.2 and $89.5 \% \mathrm{DM}, 12.1$ and $14.8 \% \mathrm{CP}, 47.7$ and $49.9 \% \mathrm{NDF}, 31.9$ and $38.4 \% \mathrm{ADF}, 3.0$ and $6.4 \%$ lignin, based on 4 samples composited by period.

${ }^{3}$ Composition of barley grain (DM basis) was $98.0 \%$ for OM; $20.5 \%$ for NDF; $7.2 \%$ for $\mathrm{ADF}$; and $12.8 \%$ for $\mathrm{CP}$.

${ }^{4} \mathrm{~A}$ registered trademark for heat-processed canola meal product (Canbra Foods, Lethbridge, Alberta, Canada).

${ }^{5}$ Contained $58.8 \% \mathrm{NaCl}, 16.0 \%$ Dynamate (Pitman Moore Inc., Mundelein, IL; $18 \% \mathrm{~K}, 11 \% \mathrm{Mg}, 22 \% \mathrm{~S}, 1,000 \mathrm{mg}$ of $\mathrm{Fe} / \mathrm{kg}$ ), $2 \%$ $\mathrm{ZnSO}_{4} \cdot \mathrm{H}_{2} \mathrm{O}, 2.4 \% \mathrm{MnSO}_{4} \cdot 4 \mathrm{H}_{2} \mathrm{O}, 0.01 \% \mathrm{CoSO}_{4} \cdot 6 \mathrm{H}_{2} \mathrm{O}, 0.009 \% \mathrm{Na}_{2}$ $\mathrm{SeO}_{3}, 0.012 \%$ ethylenediamine dihydroiodide, $0.8 \% \mathrm{CuSO}_{4} \cdot 5 \mathrm{H}_{2} \mathrm{O}$, $2,000,000 \mathrm{IU} / \mathrm{kg}$ of vitamin A, 200,000 IU/kg of vitamin D, and 2,000 $\mathrm{IU} / \mathrm{kg}$ of vitamin $\mathrm{E}$.

${ }^{6}$ Bear River Zeolite of Canada Corp. (Lethbridge, Alberta, Canada).

approved by the Agriculture and Agri-Food Canada Animal Care Committee (Lethbridge, Alberta, Canada).

Feed samples of TMR and ingredients were collected once weekly, whereas orts were collected daily and composited weekly for DM determination. Feed intake was calculated as the difference between feed offered and orts recorded daily. Samples of feeds and orts were composited by period, and then dried in an oven at $55^{\circ} \mathrm{C}$ for $48 \mathrm{~h}$ and ground through a 1-mm diameter screen (Wiley mill, standard model 4, Arthur H. Thomas Co., Philadelphia, PA) for subsequent determination of ash, NDF, $\mathrm{ADF}$, starch, and CP. Milk production was recorded at each milking. During the last $10 \mathrm{~d}$ of each 21 -d period, milk samples were collected at each milking, preserved with potassium dichromate, and subsequently analyzed for fat, crude protein, and lactose contents by using an infrared analyzer (Milk-O-Scan 605, Foss Electric, Hillerød, Denmark). 


\section{Ruminal pH, Fermentation, and Protozoa Counts}

Ruminal $\mathrm{pH}$ was monitored continuously for $72 \mathrm{~h}$ during $\mathrm{d} 13$ to 16 of each experimental period as described by Penner et al. (2006). Ruminal $\mathrm{pH}$ data were summarized daily for each cow as mean, minimum, and maximum $\mathrm{pH}$, area between the observed $\mathrm{pH}$ and a line drawn at $\mathrm{pH} 5.8$ or 5.5 , and time (h) under $\mathrm{pH} 5.8$ or 5.5 (Yang and Beauchemin, 2006).

Ruminal fluid was collected on d 16 at 0900, 1300, 1600 , and $2000 \mathrm{~h}$ from multiple sites within the rumen via the rumen cannulas. Samples were immediately squeezed through a nylon mesh (1-mm pore size), and subsamples $(5 \mathrm{~mL})$ of filtrate were preserved with $1 \mathrm{~mL}$ of $25 \%$ (wt/vol) $\mathrm{HPO}_{3}$ and $1 \mathrm{~mL}$ of $1 \% \mathrm{H}_{2} \mathrm{SO}_{4}$ for later determination of VFA and $\mathrm{NH}_{3}-\mathrm{N}$ concentrations, respectively. For protozoa enumeration, $1 \mathrm{~mL}$ of the filtrate was transferred to a vial containing $5 \mathrm{~mL}$ of methyl green-formalin-saline solution (Ogimoto and Imai, 1981). The number of protozoa $\times 10^{5}$ per milliliter was counted on a microscope at a magnification of $100 \times$ in a 0.2-mL counting chamber after serial dilution. From each sample, duplicate measurements were conducted, and the average was used to determine the number of protozoa present in the initial sample.

\section{Duodenal Flow, Apparent Digestion, and Ruminal Microbial Protein Synthesis}

Duodenal flow, digestion at different sites, and apparent total tract digestibility of nutrients were determined using $\mathrm{YbCl}_{3}$ (GFS Chemicals Inc., Powell, $\mathrm{OH}$ ) as a digesta marker. Ammonia ${ }^{15} \mathrm{~N}\left(\left[{ }^{15} \mathrm{NH}_{4}\right]_{2} \mathrm{SO}_{4}, 10.6 \%\right.$ atom $\%{ }^{15} \mathrm{~N}$, Isotec-Sigma-Aldrich Family, St. Louis, MO) was used as a ruminal microbial marker. Marker solutions containing $\mathrm{Yb}(1.2 \mathrm{~g} / \mathrm{d})$ and ammonia ${ }^{15} \mathrm{~N}(140 \mathrm{mg}$ of ${ }^{15} \mathrm{~N} / \mathrm{d}$ ), respectively, were continuously infused into the rumen via the ruminal cannula at a rate of $800 \mathrm{~mL}$ of solution/d by using an automatic peristaltic pump (model $60 \mathrm{rpm} / 7524-10$, Masterflex L/S Microprocessor pump drive, Vernon Hills, IL) during the last $11 \mathrm{~d}$ of each 21$\mathrm{d}$ period. During the last $4 \mathrm{~d}$ of each period, ruminal samples ( $\sim 750 \mathrm{~g} / \mathrm{sample})$ were collected daily from 4 different locations within the rumen, composited, and used to isolate ruminal bacteria. Duodenal samples were collected every $6 \mathrm{~h}$, moving ahead $2 \mathrm{~h}$ each day for the last $3 \mathrm{~d}$ of infusion. This schedule provided 12 representative samples of duodenal contents taken at 2 -h intervals. Duodenal samples were subdivided by using an electric drill fitted with a shaft and propeller. Each sample was split into 3 fractions that were pooled by cow within period and retained for chemical analyses or for chemical analyses after freeze-drying. Fecal samples (approximately $200 \mathrm{~g}$ of wet weight) were collected from each cow from the rectum twice daily (a.m. and p.m.), with the collection time being moved ahead at 2-h intervals over the last $6 \mathrm{~d}$ of the sampling period. Fecal samples were immediately subsampled (approximately $50 \mathrm{~g}$ ), composited across sampling times for each cow and each period, dried at $55^{\circ} \mathrm{C}$ for $48 \mathrm{~h}$, ground to pass a $1-\mathrm{mm}$ sieve (standard model 4, Arthur H. Thomas Co.), and stored for chemical analyses. A ruminal and a duodenal sample taken before infusion of markers from each cow during the first period were used to determine background concentration of the markers in samples.

Ruminal samples were processed immediately to isolate ruminal bacteria. The samples were squeezed through a nylon mesh (1-mm pore size), and the retained particles (400 g) were blended in a Waring blender (Waring Products Division, New Hartford, CT) with $400 \mathrm{~mL}$ of $0.9 \% \mathrm{NaCl}$ for $1 \mathrm{~min}$ and then squeezed through a nylon mesh (1-mm pore size). Filtrates from both squeezed and strained homogenate were mixed, centrifuged $\left(800 \times \mathrm{g}\right.$ for $15 \mathrm{~min}$ at $\left.4^{\circ} \mathrm{C}\right)$ to remove protozoa and feed particles, and the resulting supernatant was centrifuged $\left(27,000 \times g\right.$ for $30 \mathrm{~min}$ at $\left.4^{\circ} \mathrm{C}\right)$ to isolate mixed ruminal bacteria. Bacterial pellets were composited by period by cow, freeze-dried, ground with a mortar and pestle, and analyzed for $\mathrm{OM}$, total $\mathrm{N}$, and ${ }^{15} \mathrm{~N}$ for the estimation of ruminal bacterial synthesis.

\section{Blood Sampling and Laboratory Analyses}

Blood samples were obtained from each cow on d 17 and 21 of each period. At $3 \mathrm{~h}$ after feeding, blood samples were collected from the jugular vein into $10-\mathrm{mL}$ vacuum tubes containing Na heparin (Vacutainer, Becton Dickinson, Franklin Lakes, NJ). Samples were centrifuged $\left(5,000 \times g\right.$ for $20 \mathrm{~min}$ at $4^{\circ} \mathrm{C}$ ) within $20 \mathrm{~min}$, and collected plasma was immediately placed on ice, transported to the laboratory, and frozen at $-20^{\circ} \mathrm{C}$ until analyzed.

Concentrations of serum amyloid A (SAA) and haptoglobin in the plasma were determined in duplicate by ELISA kits (Tridelta Development Ltd., Greystones, Co. Wicklow, Ireland) according to the manufacturer's instructions and as described by Ametaj et al. (2005). Standards of known SAA and haptoglobin contents were provided by the manufacturer. Optical density was measured by using a microplate spectrophotometer (MRX Microplate Reader, Dynatech Laboratories, Chantilly, VA) at 450 or $630 \mathrm{~nm}$ for SAA or haptoglobin, respectively. The intra- and interassay CV were below $10 \%$. The detection limit of the assay was $0.18 \mathrm{ng} / \mathrm{mL}$ for SAA and $0.05 \mathrm{mg} / \mathrm{mL}$ for haptoglobin.

For determination of total and differential white blood cell (WBC) counts, jugular blood was collected into $\mathrm{K}_{2}$ EDTA tubes (Vacutainer, Becton Dickinson), diluted (1:100) by using the Unopette system for WBC (Becton Dickinson), and counted by using a hemocytometer 
(Bright-Line, Hausser Scientific, Horsham, PA). Nine squares of the Neubauer grid were counted in duplicate and averaged. For differential WBC counts, blood was drawn into a capillary tube and spotted onto a microscope slide. Blood smears were then prepared and stained with Camco Quik Stain (Cambridge Diagnostic Products Inc., Ft. Lauderdale, FL). A total of 100 WBC were counted and classified based on morphology.

\section{Chemical Analyses}

Dry matter was determined by oven-drying at $55^{\circ} \mathrm{C}$ for $48 \mathrm{~h}$. Analytical DM content of the samples was determined by drying at $135^{\circ} \mathrm{C}$ for $3 \mathrm{~h}$ (AOAC, 1990; method 930.15). Ash content was determined by combustion at $550^{\circ} \mathrm{C}$ overnight, and $\mathrm{OM}$ content was calculated as 100 minus the percentage of ash (AOAC, 1990; method 942.05). The NDF and ADF contents were determined by using the methods described by Van Soest et al. (1991), with $\alpha$-amylase and sodium sulfite used in the NDF procedure. Starch was determined by enzymatic hydrolysis of $\alpha$-linked glucose polymers as described by Rode et al. (1999). Ruminal VFA were quantified by GLC (Varian 3700; Varian Specialties Ltd., Brockville, Ontario, Canada) by using a $15-\mathrm{m}(0.53-\mathrm{mm}$ i.d.) fusedsilica column (DB-FFAP column, J \& W Scientific, Folsom, CA). Ammonia $\mathrm{N}$ concentrations in the ruminal and duodenal samples were determined according to the technique of Weatherburn (1967), modified to use a plate reader. Concentrations of digestive markers in the duodenal and fecal samples were determined by using inductively coupled plasma optical emission spectroscopy according to the AOAC method (1990), modified such that no $\mathrm{CaCl}_{2}$ for $\mathrm{Yb}$ determination was used during sample digestion. Total $\mathrm{N}$ was determined by the flash combustion technique (model 1500, Carlo Erba Instruments, Milan, Italy), and enrichment of ${ }^{15} \mathrm{~N}$ in the rumen bacterial and duodenal samples was analyzed by isotope ratio mass spectrometry (VG Isotech, Middlewich, UK).

\section{Calculations and Statistical Analyses}

Flows of DM to the duodenum and DM excreted in feces were calculated by dividing $\mathrm{Yb}$ actually consumed (daily amount infused, grams of $\mathrm{Yb}$ per day) by $\mathrm{Yb}$ concentration (grams of $\mathrm{Yb}$ per kilogram of DM) in the duodenal digesta or feces, respectively. Flows of other nutrients to the duodenum or feces were calculated by multiplying DM flow by their concentration in duodenal or fecal DM. Ruminal microbial protein synthesis for each cow was estimated by the ratio of ${ }^{15} \mathrm{~N}$ flow at the duodenum to ${ }^{15} \mathrm{~N}$ concentration of mixed ruminal bacteria.

Data were analyzed by using the mixed model procedure of SAS (SAS Institute, 2005) to account for effects of period, cow, and treatment. The carryover effect was initially included in the model but was removed because it was not significant. Means were compared by using the least squares mean linear hypothesis test, in which treatments were considered as a fixed effect and period and cow were considered as random effects. Data for ruminal $\mathrm{pH}$ were summarized by day and then analyzed by using the same mixed model, but with day included as a repeated measure by using compound symmetry. Similarly, data for VFA, $\mathrm{NH}_{3}-\mathrm{N}$, and protozoa were analyzed as repeated measures. Effect of sampling day (d 16 or 21) and the interaction between treatment and sampling day were included in the model as fixed effects when parameters related to plasma immune status were analyzed. The estimation method was the REML and the degrees of freedom method was Kenward-Rogers (SAS Institute, 2005). Effects of the treatments were declared significant at $P<0.05$ and trends were discussed at $P$ $<0.10$.

\section{RESULTS}

\section{Intake, Duodenal Flow, and Digestibility}

Intake of DM ranged from 19.9 to $20.7 \mathrm{~kg} / \mathrm{d}$ (i.e., 2.8 to $2.9 \%$ of BW) and was not affected by dietary treatments (Table 2). Intakes of OM, NDF, $\mathrm{ADF}$, and starch were also similar among treatments.

No effect of feeding JUN, GAR, or MO was observed for duodenal flows of DM, OM, NDF, ADF, and starch. However, the amount $(\mathrm{kg} / \mathrm{d})$ of truly fermented OM in the rumen (RFOM) was 13.5\% higher for JUN and $10.4 \%$ higher $(P<0.10)$ for GAR than for the control. The amount of RFOM did not differ between MO and the control, but was $19 \%$ lower with MO than with JUN or GAR supplementation. Consequently, digestibilities (\% of intake) of DM and $\mathrm{OM}$ in the rumen were 11.7 and $11.7 \%$ higher, respectively, for GAR and 15.2 and $14.3 \%$ higher, respectively, for JUN as compared with the control diet. Supplementation with MO decreased ruminal digestibilities of DM and OM by 18.7 and $16.0 \%$, respectively, as compared with diets supplemented with GAR or JUN.

Intestinal digestibilities (\% of intake) of DM, OM, $\mathrm{NDF}$, and starch were similar among treatments, whereas digestibility (\% of intake) of ADF tended to be higher $(P<0.10)$ for cows fed MO as compared with those fed control or JUN diets. As a result, digestibilities of nutrients in the total tract were not affected by supplementation of the diet with feed additives.

\section{N Metabolism and Ruminal Microbial Protein Synthesis}

Supplementation with GAR, JUN, or MO had no effect on N intake (Table 3). Similarly, duodenal flows of total, 
Table 2. Effects of monensin (MO), garlic (GAR), and juniper berry (JUN) essential oils on intake, duodenal flow, and the site and extent of digestion in lactating dairy cows

\begin{tabular}{|c|c|c|c|c|c|c|}
\hline \multirow[b]{2}{*}{ Item } & \multicolumn{4}{|c|}{ Treatment } & \multirow[b]{2}{*}{$\mathrm{SE}$} & \multirow[b]{2}{*}{$P<$} \\
\hline & Control & MO & GAR & JUN & & \\
\hline \multicolumn{7}{|l|}{ Intake, $\mathrm{kg} / \mathrm{d}$} \\
\hline $\mathrm{DM}$ & 20.7 & 19.9 & 20.4 & 20.5 & 0.7 & 0.68 \\
\hline $\mathrm{DM}, \%$ of BW & 2.90 & 2.78 & 2.89 & 2.88 & 0.18 & 0.60 \\
\hline $\mathrm{OM}$ & 19.3 & 18.6 & 19.1 & 19.1 & 0.6 & 0.69 \\
\hline $\mathrm{NDF}$ & 6.5 & 6.5 & 6.3 & 6.4 & 0.4 & 0.96 \\
\hline $\mathrm{ADF}$ & 4.1 & 4.1 & 4.1 & 4.0 & 0.2 & 0.92 \\
\hline Starch & 6.7 & 7.0 & 6.8 & 7.4 & 0.3 & 0.11 \\
\hline Body weight, kg & 718 & 720 & 711 & 717 & 29 & 0.41 \\
\hline \multicolumn{7}{|c|}{ Duodenal flow, $\mathrm{kg} / \mathrm{d}$} \\
\hline $\mathrm{DM}$ & 14.7 & 14.4 & 14.1 & 13.9 & 0.5 & 0.51 \\
\hline \multicolumn{7}{|l|}{$\mathrm{OM}$} \\
\hline Total & 12.7 & 12.5 & 12.0 & 11.9 & 0.4 & 0.32 \\
\hline Microbial & 3.05 & 2.85 & 3.57 & 3.67 & 0.38 & 0.20 \\
\hline NDF & 3.7 & 4.1 & 3.8 & 3.4 & 0.2 & 0.14 \\
\hline $\mathrm{ADF}$ & 2.4 & 2.7 & 2.5 & 2.3 & 0.1 & 0.25 \\
\hline Starch & 2.4 & 2.1 & 1.1 & 1.9 & 0.2 & 0.37 \\
\hline $\mathrm{RFOM},{ }^{1} \mathrm{~kg} / \mathrm{d}$ & $9.6^{\mathrm{bc}}$ & $9.0^{\mathrm{c}}$ & $10.6^{\mathrm{ab}}$ & $10.9^{\mathrm{a}}$ & 0.7 & 0.04 \\
\hline \multicolumn{7}{|c|}{ Digestibility, \% of intake } \\
\hline \multicolumn{7}{|c|}{ Rumen } \\
\hline DM (truly) ${ }^{2}$ & $49.4^{\mathrm{b}}$ & $47.2^{\mathrm{b}}$ & $55.2^{\mathrm{a}}$ & $56.9^{\mathrm{a}}$ & 2.4 & 0.01 \\
\hline $\mathrm{OM}(\text { truly) })^{2}$ & $49.6^{\mathrm{b}}$ & $48.3^{\mathrm{b}}$ & $55.4^{\mathrm{a}}$ & $56.7^{\mathrm{a}}$ & 2.3 & 0.02 \\
\hline NDF & 42.9 & 36.1 & 39.9 & 46.0 & 2.8 & 0.15 \\
\hline $\mathrm{ADF}$ & 40.7 & 34.0 & 38.0 & 40.3 & 3.6 & 0.47 \\
\hline Starch & 64.1 & 69.3 & 69.9 & 73.6 & 2.5 & 0.15 \\
\hline \multicolumn{7}{|l|}{ Intestine } \\
\hline DM & 39.4 & 42.7 & 37.6 & 37.3 & 2.8 & 0.34 \\
\hline $\mathrm{OM}$ & 36.2 & 38.9 & 33.7 & 33.2 & 2.3 & 0.23 \\
\hline NDF & 4.8 & 13.0 & 7.5 & 1.4 & 4.4 & 0.12 \\
\hline $\mathrm{ADF}$ & 1.3 & 11.6 & 5.9 & 1.1 & 4.9 & 0.10 \\
\hline Starch & 31.2 & 27.3 & 25.3 & 21.8 & 2.8 & 0.15 \\
\hline \multicolumn{7}{|l|}{ Total } \\
\hline $\mathrm{DM}$ & 68.4 & 70.2 & 68.8 & 69.0 & 1.8 & 0.69 \\
\hline $\mathrm{OM}$ & 70.0 & 71.8 & 70.6 & 70.7 & 1.7 & 0.66 \\
\hline $\mathrm{NDF}$ & 47.7 & 49.9 & 47.4 & 47.5 & 2.9 & 0.91 \\
\hline $\mathrm{ADF}$ & 42.1 & 45.6 & 43.9 & 41.4 & 3.5 & 0.82 \\
\hline Starch & 95.3 & 96.6 & 95.2 & 95.4 & 1.0 & 0.39 \\
\hline
\end{tabular}

${ }^{\mathrm{a}-\mathrm{c}}$ Means within a row with different superscripts differ $(P<0.05)$.

${ }^{1} \mathrm{RFOM}=\mathrm{OM}$ that was truly fermented in the rumen, calculated by correcting for microbial OM.

${ }^{2}$ Corrected for the microbial portion.

nonammonia $\mathrm{N}$, and microbial $\mathrm{N}$ were not different among treatments. However, duodenal flow of dietary plus endogenous $\mathrm{N}$ decreased with JUN and GAR as compared with $\mathrm{MO}$ and the control diet. Consequently, the proportion (\% of intake) of ruminal nondegradable $\mathrm{N}$ (feed + endogenous $\mathrm{N}$ ) was lower for cows fed GAR or JUN than for cows fed MO or the control diet. Rumen microbial protein efficiency ranged from 26.4 to $28.4 \mathrm{~g}$ of N/kg of RFOM and was not affected by treatments. However, the proportion of microbial $\mathrm{N}$ (\% of intake) tended to be higher for GAR or JUN than for MO $(P<$ 0.07) or the control diet $(P<0.06)$.

Ruminal digestibility of $\mathrm{N}$ decreased with $\mathrm{MO}$, whereas it increased with the addition of GAR or JUN as compared with the control diet. Intestinal digestibility of $\mathrm{N}$, expressed as a percentage of $\mathrm{N}$ entering the duodenum or of $\mathrm{N}$ intake, was similar among the treatments.
In contrast, total digestibility of protein tended $(P<0.08)$ to be lower for cows fed the GAR diet as compared with cows fed MO.

\section{Ruminal pH and Characteristic Fermentation}

Mean ruminal $\mathrm{pH}$ ranged from 6.09 to 6.15 and did not differ among treatments (Table 4). Similarly, the lowest and highest $\mathrm{pH}$ values, the area between the observed $\mathrm{pH}$ and a line drawn at $\mathrm{pH} 5.8$ or 5.5, and time (h) under $\mathrm{pH} 5.8$ or 5.5 were similar among treatments. The concentration of total VFA ranged from 127 to 131 $\mathrm{m} M$ and was not affected by dietary treatments. Neither GAR, JUN, nor MO supplementation altered molar proportions of individual VFA, the acetate-to-propionate ratio, or the concentration of $\mathrm{NH}_{3}-\mathrm{N}$. Total numbers of protozoa and the numbers of Entodina were not affected 
Table 3. Effects of monensin (MO), garlic (GAR), and juniper berry (JUN) essential oils on microbial protein synthesis and protein digestion in lactating dairy cows

\begin{tabular}{|c|c|c|c|c|c|c|}
\hline \multirow[b]{2}{*}{ Item } & \multicolumn{4}{|c|}{ Treatment } & \multirow[b]{2}{*}{$\mathrm{SE}$} & \multirow[b]{2}{*}{$P<$} \\
\hline & Control & MO & GAR & JUN & & \\
\hline $\mathrm{N}$ intake, $\mathrm{g} / \mathrm{d}$ & 555.8 & 503.6 & 503.1 & 512.3 & 21.2 & 0.18 \\
\hline \multicolumn{7}{|l|}{ Flow to duodenum } \\
\hline \multicolumn{7}{|l|}{ Total } \\
\hline $\mathrm{g} / \mathrm{d}$ & 533.1 & 514.1 & 517.6 & 531.8 & 37.8 & 0.83 \\
\hline$\%$ of intake & 95.7 & 102.1 & 102.9 & 103.8 & 5.9 & 0.39 \\
\hline \multicolumn{7}{|l|}{ NAN } \\
\hline$g / d$ & 516.6 & 498.9 & 499.8 & 514.3 & 36.3 & 0.84 \\
\hline$\%$ of intake & 92.8 & 99.1 & 99.3 & 100.4 & 5.7 & 0.41 \\
\hline Ammonia $\mathrm{N}$ & 16.5 & 15.2 & 17.8 & 17.5 & 1.8 & 0.22 \\
\hline \multicolumn{7}{|l|}{ Feed + endogenous } \\
\hline $\mathrm{g} / \mathrm{d}$ & $256.6^{\mathrm{a}}$ & $261.6^{\mathrm{a}}$ & $198.1^{\mathrm{b}}$ & $207.1^{\mathrm{b}}$ & 11.8 & 0.01 \\
\hline$\%$ of intake & $46.2^{\mathrm{b}}$ & $52.0^{\mathrm{a}}$ & $39.6^{\mathrm{c}}$ & $40.4^{\mathrm{c}}$ & 1.8 & 0.01 \\
\hline \multicolumn{7}{|l|}{ Microbial } \\
\hline $\mathrm{g} / \mathrm{d}$ & 259.9 & 237.2 & 301.7 & 307.2 & 31.0 & 0.19 \\
\hline$\%$ of intake & 46.6 & 47.1 & 59.7 & 60.0 & 5.4 & 0.09 \\
\hline $\mathrm{g} / \mathrm{kg}$ of $\mathrm{RFOM}^{1}$ & 27.1 & 26.4 & 28.2 & 28.4 & 2.3 & 0.89 \\
\hline \multicolumn{7}{|l|}{ Digestibility } \\
\hline Ruminal (truly), $\%$ & $53.9^{b}$ & $48.0^{\mathrm{c}}$ & $60.4^{\mathrm{a}}$ & $59.6^{\mathrm{a}}$ & 1.8 & 0.01 \\
\hline \multicolumn{7}{|l|}{ Postruminal } \\
\hline$\%$ of intake & 64.8 & 72.3 & 69.0 & 72.4 & 7.4 & 0.36 \\
\hline$\%$ of flow to duodenum & 66.4 & 69.3 & 65.1 & 68.1 & 3.9 & 0.16 \\
\hline $\mathrm{ADTT}^{3} \%$ of intake & 69.1 & 70.2 & 66.2 & 68.6 & 1.3 & 0.09 \\
\hline
\end{tabular}

${ }^{\mathrm{a}-\mathrm{c}}$ Means within a row with different superscripts differ $(P<0.05)$.

${ }^{1} \mathrm{RFOM}=$ ruminally fermented $\mathrm{OM}$.

${ }^{2} \mathrm{ADTT}=$ apparent digestibility in the total tract.

Table 4. Effects of monensin (MO), garlic (GAR), and juniper berry (JUN) essential oils on ruminal pH, fermentation characteristics, and protozoa numbers of lactating dairy cows

\begin{tabular}{|c|c|c|c|c|c|c|}
\hline \multirow[b]{2}{*}{ Item } & \multicolumn{4}{|c|}{ Treatment } & \multirow[b]{2}{*}{$\mathrm{SE}$} & \multirow[b]{2}{*}{$P<$} \\
\hline & Control & MO & GAR & JUN & & \\
\hline \multicolumn{7}{|l|}{$\mathrm{pH}$} \\
\hline Mean & 6.12 & 6.13 & 6.15 & 6.09 & 0.13 & 0.94 \\
\hline Minimum & 5.36 & 5.43 & 5.35 & 5.34 & 0.19 & 0.88 \\
\hline Maximum & 6.69 & 6.74 & 6.76 & 6.79 & 0.05 & 0.58 \\
\hline Area under $\mathrm{pH} 5.8, \mathrm{pH} \times \mathrm{h} / \mathrm{d}$ & 1.66 & 0.89 & 1.60 & 2.09 & 0.90 & 0.44 \\
\hline Area under $\mathrm{pH} 5.5, \mathrm{pH} \times \mathrm{h} / \mathrm{d}$ & 0.54 & 0.19 & 0.68 & 1.11 & 0.60 & 0.69 \\
\hline $\mathrm{pH}<5.8, \mathrm{~h} / \mathrm{d}$ & 6.47 & 4.19 & 5.51 & 6.00 & 2.01 & 0.71 \\
\hline $\mathrm{pH}<5.5, \mathrm{~h} / \mathrm{d}$ & 3.18 & 1.79 & 2.46 & 3.87 & 1.62 & 0.98 \\
\hline \multicolumn{7}{|l|}{ VFA } \\
\hline Total, mM & 128.7 & 130.6 & 126.8 & 127.9 & 6.3 & 0.88 \\
\hline \multicolumn{7}{|l|}{$\mathrm{Mol} / 100 \mathrm{~mol}$} \\
\hline Acetate (A) & 60.7 & 58.5 & 60.1 & 59.5 & 3.3 & 0.44 \\
\hline Propionate (P) & 24.7 & 26.2 & 25.6 & 25.7 & 3.7 & 0.90 \\
\hline Butyrate & 10.2 & 10.7 & 10.0 & 10.5 & 0.6 & 0.68 \\
\hline $\mathrm{BCFA}^{1}$ & 2.2 & 2.6 & 2.4 & 2.3 & 0.2 & 0.43 \\
\hline Valerate & 1.6 & 1.6 & 1.6 & 1.6 & 0.1 & 0.96 \\
\hline Caproic & 0.5 & 0.4 & 0.4 & 0.4 & 0.2 & 0.81 \\
\hline $\mathrm{A}: \mathrm{P}$ & 2.72 & 2.46 & 2.60 & 2.69 & 0.62 & 0.71 \\
\hline $\mathrm{NH}_{3}-\mathrm{N}, \mathrm{m} M$ & 5.45 & 4.94 & 5.51 & 5.01 & 0.72 & 0.79 \\
\hline \multicolumn{7}{|l|}{ Protozoa, $\times 10^{5}$} \\
\hline Isotricha & 0.29 & 0.24 & 0.23 & 0.36 & 0.04 & 0.10 \\
\hline Entodina & 4.80 & 4.58 & 4.80 & 5.58 & 1.37 & 0.80 \\
\hline Total & 5.09 & 4.82 & 5.03 & 5.94 & 1.38 & 0.75 \\
\hline
\end{tabular}

${ }^{1} \mathrm{BCFA}=$ branched-chain fatty acids (isobutyrate + isovalerate). 
Table 5. Effects of monensin (MO), garlic (GAR), and juniper berry (JUN) essential oils on milk production and composition of lactating dairy cows

\begin{tabular}{|c|c|c|c|c|c|c|}
\hline \multirow[b]{2}{*}{ Item } & \multicolumn{4}{|c|}{ Treatment } & \multirow[b]{2}{*}{$\mathrm{SE}$} & \multirow[b]{2}{*}{$P<$} \\
\hline & Control & MO & GAR & JUN & & \\
\hline \multicolumn{7}{|c|}{ Milk yield, $\mathrm{kg} / \mathrm{d}$} \\
\hline Actual & 29.0 & 28.9 & 29.9 & 29.4 & 2.1 & 0.44 \\
\hline $4 \% \mathrm{FCM}^{1}$ & 25.1 & 23.3 & 27.6 & 26.9 & 2.5 & 0.06 \\
\hline $\mathrm{SCM}^{2}$ & 25.0 & 23.5 & 27.0 & 26.5 & 2.4 & 0.06 \\
\hline \multicolumn{7}{|l|}{ Milk fat } \\
\hline$\%$ & $3.14^{\mathrm{a}}$ & $2.68^{b}$ & $3.46^{\mathrm{a}}$ & $3.40^{\mathrm{a}}$ & 0.31 & 0.01 \\
\hline $\mathrm{kg} / \mathrm{d}$ & $0.90^{\mathrm{a}}$ & $0.78^{b}$ & $1.04^{\mathrm{a}}$ & $1.01^{\mathrm{a}}$ & 0.12 & 0.03 \\
\hline \multicolumn{7}{|l|}{ Milk CP } \\
\hline$\%$ & 3.31 & 3.25 & 3.23 & 3.28 & 0.05 & 0.48 \\
\hline $\mathrm{kg} / \mathrm{d}$ & 0.96 & 0.94 & 0.96 & 0.96 & 0.06 & 0.56 \\
\hline \multicolumn{7}{|l|}{ Milk lactose } \\
\hline$\%$ & 4.44 & 4.47 & 4.46 & 4.46 & 0.07 & 0.53 \\
\hline $\mathrm{kg} / \mathrm{d}$ & 1.29 & 1.30 & 1.33 & 1.31 & 0.11 & 0.47 \\
\hline \multicolumn{7}{|l|}{ Milk efficiency } \\
\hline Actual:DMI & 1.40 & 1.45 & 1.47 & 1.43 & 0.09 & 0.77 \\
\hline FCM:DMI & 1.21 & 1.17 & 1.35 & 1.31 & 0.10 & 0.19 \\
\hline $\mathrm{SCC}, 10^{5} / \mathrm{mL}$ & 4.69 & 4.07 & 4.00 & 2.46 & 2.02 & 0.68 \\
\hline
\end{tabular}

a,b Means within a row with different superscripts differ $(P<0.05)$.

${ }^{1} \mathrm{FCM}=$ milk $\times($ fat $\% \times 0.15+0.4)$.

${ }^{2} \mathrm{SCM}=$ milk $\times(0.1224 \times$ fat $\%+0.071 \times$ protein $\%+0.0635 \times$ lactose $\%-0.0345)$.

by treatment. However, the number of Isotricha tended $(P<0.08)$ to increase with the addition of JUN as compared with MO or GAR.

\section{Milk Production and Milk Composition}

Milk production ranged from 28.9 to $29.9 \mathrm{~kg} / \mathrm{d}$ and was not different among the treatments (Table 5). Production of 4\% FCM and SCM was not affected by GAR, JUN, or MO supplementation compared with the control diet. However, cows fed MO tended $(P<0.06)$ to produce less $4 \%$ FCM $(-17 \%)$ and SCM $(-14 \%)$ than cows fed diets supplemented with GAR, and this was related to the lower milk fat content in cows fed the MO diet (2.68\%) as compared with cows fed GAR (3.46\%). Milk fat content tended $(P<0.10)$ to be $10 \%$ higher for the GAR diet than for the control diet. Milk protein and milk lactose contents as well as their yields were not affected by the treatments. Similarly, milk efficiency, expressed either as kilograms of milk or as FCM per kilogram of DMI, was not different among the treatments.

\section{Immune Status}

There were no interactions between day and treatment of total WBC, differential WBC counts, or concentrations of SAA and haptoglobin in the plasma (data not shown). These data indicated that feeding MO or EO from GAR and JUN had no effect on the immune status of the cows (Table 6).

\section{DISCUSSION}

Results of this study indicate that supplementing dairy cows with GAR and JUN had no effect on DMI. The effects of feeding EO or their components have been reported to vary according to the type of EO (Cardozo et al., 2006) and the interaction of EO with other feed additives in the diet, such as MO (Benchaar et al., 2006b). Cardozo et al. (2006) reported that supplementation of a mixture of cinnamaldehyde $(0.6 \mathrm{~g} / \mathrm{d})$ and eugenol $(0.3 \mathrm{~g} / \mathrm{d})$ oils decreased DMI, whereas feeding capsicum oil ( $1 \mathrm{~g} / \mathrm{d}$ of capsicum extract containing $15 \%$ capsaicin) increased DMI in Holstein heifers. Furthermore, Benchaar et al. (2006b) showed that feeding dairy cows 2 $\mathrm{g} / \mathrm{d}$ of EO containing a mixture of thymol, eugenol, vanillin, and limonene decreased DMI. In contrast, when this mixture was fed in combination with MO, DMI was increased.

Supplementation with MO did not affect DMI in the present study, which agrees with the results of some reports (Plaizier et al., 2000; Broderick, 2004; Benchaar et al., 2006b) but contrasts with other studies (Sauer et al., 1998; Ruiz et al., 2001). In dairy cows, feed intake could be influenced by a number of factors, such as BW, lactation stage, physical fill, digestion, passage rate, or fermentation metabolites (Allen, 2000).

Although supplementation with GAR or JUN increased ruminal digestibilities of DM and $\mathrm{OM}$ as compared with the control diet, the total-tract digestibilities of DM and OM remained unaffected by feeding these 2 $\mathrm{EO}$ to cows. The lack of influence of $\mathrm{EO}$ on total-tract 
Table 6. Effects of monensin (MO), garlic (GAR), and juniper berry (JUN) essential oils on the immune status of lactating dairy cows

\begin{tabular}{lcccccr}
\hline & \multicolumn{7}{c}{ Treatment } & & \\
\cline { 2 - 5 } Item & Control & MO & GAR & JUN & SE & $P<$ \\
\hline White blood cells, $\times 10^{3} / \mu \mathrm{L}$ & 6.30 & 6.60 & 6.22 & 6.21 & 0.85 & 0.95 \\
Lymphocyte, \% & 56.4 & 55.5 & 52.3 & 56.9 & 3.2 & 0.79 \\
Neutrophil, \% & 32.3 & 29.8 & 34.6 & 30.5 & 4.2 & 0.48 \\
Monocyte, \% & 6.4 & 8.8 & 6.9 & 6.1 & 1.2 & 0.33 \\
Eosinophil, \% & 4.4 & 5.4 & 6.0 & 5.8 & 1.4 & 0.48 \\
Basophil, \% & 0.1 & 0.3 & 0.3 & 0.3 & 0.2 & 0.78 \\
Haptoglobin, $\mu \mathrm{g} / \mathrm{mL}$ & 681 & 623 & 544 & 583 & 123 & 0.78 \\
SAA, ${ }^{1} \mu \mathrm{g} / \mathrm{mL}$ & 74.8 & 67.0 & 79.6 & 66.4 & 27.1 & 0.96 \\
\hline
\end{tabular}

${ }^{1} \mathrm{SAA}=$ serum amyloid $\mathrm{A}$.

digestibilities of $\mathrm{DM}$ and $\mathrm{OM}$ is in agreement with previous observations with dairy cows (Benchaar et al., 2006b) and beef cattle (Benchaar et al., 2006a). The improved ruminal digestion of OM with JUN was mainly related to the increased ruminal digestion of protein.

The effect of $\mathrm{MO}$ on the intestinal digestibility of $\mathrm{ADF}$ observed in the current study is in agreement with the findings of Ali-Haïmoud et al. (1995), who reported a reduction in the digestibility of $\mathrm{ADF}$ in the rumen, but not in the total tract. Osborne et al. (2004) observed that supplementation with MO increased postruminal NDF digestion and shifted NDF digestion from the rumen to the intestines. The influence of $\mathrm{MO}$ on ruminal or postruminal digestion of $\mathrm{DM}, \mathrm{NDF}$, or $\mathrm{N}$ has not been consistent (Plaizier et al., 2000; Osborne et al., 2004; Benchaar et al., 2006b). The discrepancies among studies may be attributed to different amounts of MO supplemented (Sauer et al., 1998; Broderick, 2004), the forageto-concentrate ratio, or the stage of lactation (Plaizier et al., 2000).

Similar intakes of $\mathrm{N}$ between the control diet and diets supplemented with GAR and JUN are consistent with the lack of influence of these EO on DMI. The decrease in the duodenal flow of dietary $\mathrm{N}$ and the increase in ruminal N digestibility with GAR or JUN supplementation suggest that the proteolytic activity in the rumen was stimulated. However, ruminal concentration of $\mathrm{NH}_{3}-\mathrm{N}$ was not increased by GAR and JUN supplementation. The impact of these EO on CP digestibility in our study contrasts with previous in vitro (Busquet et al., 2005b, 2006) or in situ (Molero et al., 2004; Benchaar et al., 2006b) studies. For example, Busquet et al. (2005b) reported no changes in protein degradation when GAR was added at 31.2 or $312.0 \mathrm{mg} / \mathrm{L}$ in a continuous culture system maintained at constant $\mathrm{pH}$. Similarly, Benchaar et al. (2006b) showed no effect on in situ effective ruminal degradability of $\mathrm{N}$ of soybean meal incubated in the rumen of lactating cows supplemented with $2 \mathrm{~g} / \mathrm{d}$ of a mixture of EO compounds. The discrepancy between the current study and those studies can be attributed to the differences in experiments (in vivo vs. in vitro or in situ), type or dose of EO, and diet composition. The lack of effect of GAR supplementation on ruminal $\mathrm{N}$ degradation in the studies of Busquet et al. (2005a,c) could be due to a higher dosage of GAR (31.2 to $312 \mathrm{mg} / \mathrm{L}$ ) compared with the current dose $(20.8 \mathrm{mg} / \mathrm{L})$. Garlic oil has antimicrobial activity (Feldberg et al., 1988), and a high dose of GAR could have detrimental effects on ruminal fermentation. For instance, Busquet et al. (2005a) reported that the molar proportion of acetate was reduced $(P<0.05)$ by $11 \%$ and NDF digestibility was decreased by $22 \%$ when $312 \mathrm{mg}$ of GAR/L was added to in vitro batch culture rumen fermentation at a constant $\mathrm{pH}$. In the current study, increased RFOM with GAR supplementation suggests increased energy availability to ruminal microorganisms.

Several studies have suggested that EO and their active components may conserve AA from ruminal degradation by inhibiting microbial deamination (McIntosh et al., 2003; Newbold et al., 2004). However, Molero et al. (2004) speculated that the effects of EO on N metabolism may result from the inhibition of proteolytic activity or a decrease in the attachment and colonization of feed by proteolytic microbes. Our results suggest that these in vitro observations may not be relevant in vivo, because we observed an increase, as opposed to a decrease, in protein degradation in the rumen as a result of supplementation of the diet with JUN.

The lack of an effect of GAR and JUN on duodenal microbial protein flow is consistent with the results of Busquet et al. (2005a) and Castillejos et al. (2007), who observed no change in bacterial $\mathrm{N}$ flow in a dual-flow continuous culture supplied with GAR (312 $\mathrm{mg} / \mathrm{L})$ or a mixture of EO compounds (5, 50, and $500 \mathrm{mg} / \mathrm{L})$. Benchaar et al. (2007) also reported no change in duodenal bacterial flow in cows fed $750 \mathrm{mg} / \mathrm{d}$ of a mixture of EO compounds.

Feeding MO decreased ruminal CP degradation, which agrees with a previous observation by Ali-Haïmoud et al. (1995). Monensin has been recognized for 
its ability to reduce $\mathrm{NH}_{3}-\mathrm{N}$ concentration in the rumen owing to inhibition of peptide and AA catabolism (Whetstone et al., 1981). The lack of an effect of MO supplementation on the total digestibility of CP in our study contrasts with the results reported by Benchaar et al. (2006b) and Plaizier et al. (2000), who observed increased digestibility of $\mathrm{CP}$ in the total tract of dairy cows fed MO. The improved total digestibility of $\mathrm{CP}$ attributable to supplementation of MO has been explained by a greater proportion of dietary protein escaping ruminal degradation (Plaizier et al., 2000). The digestibility of dietary protein in the small intestine is usually higher than that of microbial protein (Van Soest, 1994). However, this is not supported by the present findings. In fact, the digestibility of $\mathrm{CP}$ in the intestine was not reduced, even though the proportion (\% of total $\mathrm{N}$ flow at the duodenum) of dietary $\mathrm{N}$ was lower and that of microbial $\mathrm{N}$ was higher for diets supplemented with GAR (38 and 58\%, respectively) and JUN (39 and 58\%, respectively) compared with the control (48 and 49\%, respectively; data not shown). Digestibility of microbial $\mathrm{N}$ in the small intestine is relatively constant $(80 \%)$, whereas that of escaped feed $\mathrm{N}$ varies substantially from 50 to $100 \%$ depending on the feed source (NRC, 2001).

Ruminal $\mathrm{pH}$ and total VFA concentration were unaffected by the addition of GAR and JUN. These results are not consistent with increased ruminal digestion of OM observed for diets supplemented with GAR or JUN as compared with the control. This discrepancy may be explained by the fact that concentration of VFA in the rumen reflects the equilibrium between absorption and production of VFA rather than having a direct relationship with rumen digestion of OM. In fact, total VFA concentration and the acetate-to-propionate ratio were also not affected by MO supplementation. Although the alteration in molar proportion of VFA, with an increase in propionate and a decrease in acetate, is a common response to MO supplementation (Ruiz et al., 2001; Mutsvangwa et al., 2002), other studies have reported that MO supplementation does not affect VFA concentration (Ali-Haïmoud et al., 1995). Mutsvangwa et al. (2002) suggested that the discrepancies among studies may include differences in dietary inclusion levels of $\mathrm{MO}$, and in interactions between feed intake and composition, and MO. In a recent study, Benchaar et al. (2006b) observed that a tendency for a decrease in the acetate-to-propionate ratio (from 2.98 to $2.81, P<0.15$ ) might be related to the low amount of MO in the $\operatorname{diet}(16 \mathrm{mg} / \mathrm{kg}$ of DM). The amount of MO supplemented in the present study (i.e., $16.5 \mathrm{mg} / \mathrm{kg}$ of DM) was similar to that of Benchaar et al. (2006b).

Similarly, Benchaar et al. (2006b) observed that supplementation of cows with a mixture of EO compounds had no effect on concentration of total VFA or on molar proportions of individual VFA. The lack of an effect of GAR or JUN on molar proportion of butyrate in the rumen is consistent with the results obtained from dairy cows supplemented with a mixture of EO, including thymol, eugenol, vanillin, gaiacol, and limonene (Benchaar et al., 2006b, 2007). However, it contrasts with the in vitro results of Busquet et al. (2005a, 2006), who reported that the effect of GAR on increasing proportions of butyrate was dose dependent.

Little information exists on the effect of $\mathrm{EO}$ and their compounds on ciliate protozoa populations in the rumen. Cardozo et al. (2006) observed increased numbers of holotrichs in cows fed a mixture of cinnamaldehyde $(0.6 \mathrm{~g} /$ d) and eugenol $(0.3 \mathrm{~g} / \mathrm{d})$. Benchaar et al. (2006b, 2007) reported no change in the numbers of protozoa in ruminal fluid of cows fed $2 \mathrm{~g} / \mathrm{d}$ or $750 \mathrm{mg} / \mathrm{d}$ of a commercial mixture of EO compounds, respectively. Modification in the numbers of Isotricha in the current study may suggest that the effects of JUN are not limited to the bacterial population only, but also to other rumen inhabitants.

Another finding of this research was the increase of milk fat content with GAR $(P<0.10)$ as compared with milk fat content with the control diet. The mechanism by which GAR increased milk fat content is not clear, because DMI and fiber digestibility in the rumen were not different between cows fed GAR and those fed the control diet. The present findings are not in agreement with the results of Benchaar et al. (2006b, 2007), who observed no change in milk yield and milk composition in cows supplemented with $2 \mathrm{~g} / \mathrm{d}$ or $750 \mathrm{mg} / \mathrm{d}$ of a commercial mixture of EO compounds, respectively. However, the type and the dose of EO supplement were different between the current study and those of Benchaar et al. (2006b, 2007).

The present results showed that feeding MO depressed milk fat content, although milk production was not affected. These results are in agreement with previous investigations using dairy cows supplemented with MO (Broderick, 2004; Benchaar et al., 2006b). The deceased milk fat content with $\mathrm{MO}$ supplementation might be related to changes in milk concentration of trans 18:1 in the current study. Benchaar et al. (2006b) reported that cows fed MO produced milk with greater concentrations of trans-10 18:1 (+17\%) and trans-11 18:1 (+16\%) than control cows. Increased concentration of trans -10 18:1 in milk has been associated with decreased milk fat concentration (Griinari et al., 1998). The effects on milk protein content of feeding MO have been variable. Our results corroborate those of Sauer et al. (1998) and Benchaar et al. (2006b), who observed no change in milk protein content, but they disagree with the results reported by Phipps et al. (2000) and Broderick (2004), who observed a decrease in milk protein content in cows supplemented with 10 to $15 \mathrm{mg}$ of $\mathrm{MO} / \mathrm{kg}$ of $\mathrm{DM}$ of diet. 
In the latter 2 reports, the reduction of milk protein content with MO supplementation was explained by a dilution effect because of increased milk production. In our study, the lack of effect of MO on milk protein content might be related to similar duodenal $\mathrm{N}$ flows of nonammonia $\mathrm{N}$, microbial $\mathrm{N}$, and dietary $\mathrm{N}$.

Although EO and their compounds have been shown to have antimicrobial and antioxidant activity (Hammer et al., 1999), information on their immunomodulatory effects in ruminants is lacking. Supplementation with GAR and JUN had no effect on the total number or the differential counts of WBC, or on SAA and haptoglobin concentrations. The concentrations of these 2 acute phase proteins were higher than expected for a midlactating cow. Usually, the release of acute phase proteins is attributed to activation of the immune system in conditions such as inflammation, tissue injury, and infection (Suffredini et al., 1999). The main function of SAA is to bind and neutralize endotoxin and carry it to the liver to be excreted in bile. Haptoglobin also is increased in plasma when there is translocation of bacteria into the bloodstream. Haptoglobin binds hemoglobin and prevents utilization of iron contained in hemoglobin by bacteria. The latter need iron for their growth and multiplication. Although the reason for high plasma SAA and haptoglobin concentrations in our midlactating cows is not clear, one of the reasons for increased acute phase proteins may be related to the high-grain diet fed to the cows (i.e., 60\% barley grain-based concentrate, DM basis). Feeding cattle high proportions of grain has been shown to increase the amount of endotoxin in rumen fluid and its translocation into the bloodstream (Andersen et al., 1994). Thus, inclusion of a high proportion of grain and the potential translocation of endotoxin into the bloodstream might explain the high levels of SAA and haptoglobin in our study.

\section{CONCLUSIONS}

Addition of GAR ( $5 \mathrm{~g} / \mathrm{kg}$ of DM) or JUN ( $2 \mathrm{~g} / \mathrm{kg}$ of $\mathrm{DM}$ ) in the diet of dairy cows increased truly ruminal digestibility of DM and $\mathrm{OM}$ as well as the amount of rumen-fermented OM. Improved ruminal digestibility of $\mathrm{DM}$ and OM with supplementation of GAR and JUN was mainly due to increased CP digestibility in the rumen. However, supplementation of GAR and JUN in the dairy cow diets had no effects on feed intake, ruminal fermentation characteristics, digestibility in the total tract, milk production, or milk composition. The immune status of dairy cows was also not changed with addition of GAR and JUN. These results suggest that addition of GAR or JUN had minimal beneficial effects on dairy cows; although EO improved feed digestibility in the rumen, it was possibly at the expense of a reduction in the flow of bypass protein to the small intestine.

Supplementing MO (16 mg/kg of DM) in the diets of dairy cows reduced ruminal protein degradability and milk fat content. Feeding MO to dairy cows did not affect feed intake, total digestibility, rumen fermentation, milk production, and immune status. The results suggest that supplementation with MO was beneficial in terms of increasing bypass protein from the rumen, but it did not alter feed digestion or milk production under the experimental conditions of the current study.

\section{ACKNOWLEDGMENTS}

The authors are thankful to K. Andrews, B. Farr, A. Furtado, K. Gill, A. Joseph, D. Vedres, and R. Wuerfel for their assistance in sample collection and laboratory analyses as well as to the technical staff of Lethbridge Research Centre, Dairy Unit, for their continuous help with the care of the cows and collection of milk samples.

\section{REFERENCES}

Ali-Haïmoud, D., M. Vernay, C. Bayourthe, and R. Moncoulon. 1995. Avoparcin and monensin effects on the digestion of nutrients in dairy cows fed a mixed diet. Can. J. Anim. Sci. 75:379-385.

Allen, M. S. 2000. Effects of diet on short-term regulation of feed intake by lactating dairy cattle. J. Dairy Sci. 83:1598-1624.

Ametaj, B. N., B. J. Bradford, G. Bobe, R. A. Nafikov, Y. Lu, J. W. Young, and D. C. Beitz. 2005. Strong relationship between mediators of the acute phase response and fatty liver in dairy cows. Can. J. Anim. Sci. 85:165-175.

Andersen, P. H., B. Bergelin, and K. A. Christensen. 1994. Effect of feeding regimen on concentration of free endotoxin in ruminal fluid of cattle. J. Anim. Sci. 72:487-491.

AOAC. 1990. Official Methods of Analysis. Vol. 1. 15th ed. Assoc. Off. Anal. Chem., Arlington, VA.

Benchaar, C., J. L. Duynisveld, and E. Charmley. 2006a. Effects of monensin and increasing dose levels of a mixture of essential oil compounds on intake, digestion and growth performance of beef cattle. Can. J. Anim. Sci. 86:91-96.

Benchaar, C., H. V. Petit, R. Berthiaume, T. D. Whyte, and P. Y. Chouinard. 2006b. Effects of addition of essential oils and monensin premix on digestion, ruminal fermentation, milk production, and milk composition in dairy cows. J. Dairy Sci. 89:4352-4364.

Benchaar, C., H. V. Petit, R. Berthiaume, D. R. Ouellet, J. Chiquette, and P. Y. Chouinard. 2007. Effects of essential oils on digestion, ruminal fermentation, rumen microbial populations, milk production, and milk composition in dairy cows fed alfalfa silage or corn silage. J. Dairy Sci. 90:886-897.

Broderick, G. A. 2004. Effect of low level monensin supplementation on the production of dairy cows fed alfalfa silage. J. Dairy Sci. 87:359-368.

Busquet, M., S. Calsamiglia, A. Ferret, M. D. Carro, and C. Kamel. 2005a. Effects of garlic oil and four of its compounds on rumen microbial fermentation. J. Dairy Sci. 88:4393-4404.

Busquet, M., S. Calsamiglia, A. Ferret, and C. Kamel. 2005b. Screening for effects of plant extracts and active compounds of plant on dairy cattle rumen microbial fermentation in a continuous culture system. Anim. Feed Sci. Technol. 123-124:597-613.

Busquet, M., S. Calsamiglia, A. Ferret, and C. Kamel. 2005c. Effects of cinnamaldehyde, garlic oil on ruminal microbial fermentation in a dual flow continuous culture. J. Dairy Sci. 88:2508-2516. 
Busquet, M., S. Calsamiglia, A. Ferret, and C. Kamel. 2006. Plant extracts affect in vitro rumen microbial fermentation. J. Dairy Sci. 89:761-771.

Cardozo, P. W., S. Calsamiglia, A. Ferret, and C. Kamel. 2006. Effects of alfalfa extracts, anise, capsicum, and a mixture of cinnamaldehyde and eugenol on ruminal fermentation and protein degradation in beef heifers fed a high-concentrate diet. J. Anim. Sci. 84:2801-2808.

Castillejos, L., S. Calsamiglia, A. Ferrer, and R. Losa. 2007. Effects of dose and adaptation time of a specific blend of essential oil compounds on rumen fermentation. Anim. Feed Sci. Technol. 132:186-201.

Chiquette J., and C. Benchaar. 2005. Effects of different dose levels of essential oils compounds on in vitro methane production by mixed ruminal bacteria. J. Dairy Sci. (Suppl. 1)83:306. (Abstr.)

Concha, C., S. Hu, and O. Holmberg. 1996. The proliferative responses of cow stripping milk and blood lymphocytes to pokeweed mitogen and ginseng in vitro. Vet. Res. 27:107-115.

Conner, D. E. 1993. Naturally occurring compounds. Pages 441-468 in Antimicrobials in Foods. P. M. Davidson and A. L. Branen, ed. Marcel Dekker, New York, NY.

Feldberg, R. S., S. C. Chang, A. N. Kotik, M. Nadler, Z. Neuwirth, D. C. Sundstrom, and N. H. Thompson. 1988. In vitro mechanism of inhibition of bacterial cell growth by allicin. Antimicrob. Agents Chemother. 32:1763-1768.

Griinari, J. M., D. A. Dwyer, M. A. McGuire, D. E. Baunan, D. L. Palmquist, and K. V. V. Nurmela. 1998. Trans-octadecenoic acids and milk fat depression in lactating dairy cows. J. Dairy Sci. 81:1251-1261.

Hammer, K. A., C. F. Carson, and T. V. Riley. 1999. Antimicrobial activity of essential oils and other plant extracts. J. Appl. Microbil. 86:985-990.

McGuffey, R. K., L. F. Richardson, and J. I. D. Wilkinson. 2001. Ionophores for dairy cattle: Current status and future outlook. J. Dairy Sci. 84(E-Suppl.):E194-E203.

McIntosh, F. M., P. Williams, R. Losa, R. J. Wallace, D. A. Beever, and C. J. Newbold. 2003. Effects of essential oils on ruminal microorganisms and their protein metabolism. Appl. Environ. Microbiol. 69:5011-5014

Molero, R., M. Ibara, S. Calsamiglia, A. Ferret, and R. Losa. 2004 Effects of a specific blend of essential oil compounds on dry matter and crude protein degradability in heifers fed diets with different forage to concentrate ratios. Anim. Feed Sci. Technol. 114:91-104.

Mutsvangwa, T., J. P. Walton, J. C. Plaizier, T. F. Duffield, R. Bagg, P. Dick, G. Vessie, and B. W. McBride. 2002. Effects of a monensin controlled-release capsule or premix on attenuation of subacute ruminal acidosis in dairy cows. J. Dairy Sci. 85:3454-3461.

NRC. 2001. Nutrient Requirements of Dairy Cattle. 7th rev. ed. Nat. Acad. Press, Washington, DC.

Newbold, C. J., F. M. McIntosh, P. Williams, R. Losa, and R. J. Wallace. 2004. Effects of a specific blend of essential oil compounds on rumen fermentation. Anim. Feed Sci. Technol. 114:105-112.

Ogimoto, K., and S. Imai. 1981. Atlas of Rumen Microbiology. Japan Scientific Societies Press, Tokyo, Japan.
Osborne, J. K., T. Mutsvangwa, O. Alzahal, T. F. Duffield, R. Bagg, P. Dick, G. Vessie, and B. W. McBride. 2004. Effect of monensin on ruminal forage degradability and total tract diet digestibility in lactating dairy cows during grain-induced subacute ruminal acidosis. J. Dairy Sci. 87:1840-1847.

Page, S. W. 2006. Current use of antimicrobial growth promoters in food animals: The benefits. Pages 19-51 in Antimicrobial Growth Promoters-Where Do We Go from Here? Wageningen Academic Publishers, the Netherlands.

Penner, G. B., K. A. Beauchemin, and T. Mutsvangwa. 2006. An evaluation of the accuracy and precision of a stand-alone submersible continuous ruminal $\mathrm{pH}$ measurement system. J. Dairy Sci. 89:2132-2140.

Phipps, R. H., J. I. Wilkinson, L. J. Jonker, M. Tarrant, A. K. Jones, and A. Hodge. 2000. Effect of monensin on milk production of Holstein-Friesian dairy cows. J. Dairy Sci. 83:2789-2794.

Plaizier, J. C., A. Martin, T. Duffield, R. Bagg, P. Dick, and B. W. McBride. 2000. Effect of a prepartum administration of monensin in a controlled-release capsule on apparent digestibilities and nitrogen utilization in transition dairy cows. J. Dairy Sci. 83:2918-2925.

Rode, L. M., W. Z. Yang, and K. A. Beauchemin. 1999. Fibrolytic enzyme supplements for dairy cows in early lactation. J. Dairy Sci. 82:2121-2126.

Ruiz, R., G. L. Albrecht, L. O. Tedeschi, G. Jarvis, J. B. Russell, and D. G. Fox. 2001. Effect of monensin on the performance and nitrogen utilization of lactating dairy cows consuming fresh forage. J. Dairy Sci. 84:1717-1727.

SAS Institute. 2005. SAS Online Doc ${ }^{\circledR}$ version 9.1.3. SAS Inst., Inc., Cary, NC.

Sauer, F. D., V. Fellner, R. Kinsman, J. K. G. Kramer, H. A. Jackson, A. J. Lee, and S. Chen. 1998. Methane output and lactation response in Holstein cattle with monensin or unsaturated fat added to the diet. J. Anim. Sci. 76:906-914.

Suffredini, A. F., G. Fantuzzi, R. Badolato, J. J. Oppenheim, and N. O'Grady. 1999. New insights into the biology of the acute phase response. J. Clin. Immunol. 19:203-214.

Tedeschi, L. Q., D. G. Fox, and T. P. Tylutki. 2003. Potential environmental benefits of ionophores in ruminant diets. J. Environ. Qual. 32:1591-1602.

Van Soest, P. J., J. B. Robertson, and B. A. Lewis. 1991. Methods for dietary fiber, neutral detergent fiber and non-starch polysaccharide in relation to animal nutrition. J. Dairy Sci. 74:3583-3597.

Van Soest, P. J. 1994. Nitrogen metabolism. Pages 290-311 in Nutritional Ecology of the Ruminant. Cornell University Press, Ithaca, NY.

Weatherburn, M. W. 1967. Phenol-hypochlorite reaction for determination of ammonia. Anal. Chem. 39:971-974

Whetstone, H. D., C. L. Davis, and M. P. Bryant. 1981. Effect of monensin on breakdown of protein by ruminal microorganisms in vitro. J. Anim. Sci. 53:803-809.

Yang, W. Z., and K. A. Beauchemin. 2006. Increasing physically effective fiber content of dairy cow diets may lower efficiency of feed use. J. Dairy Sci. 89:2694-2704. 